\title{
Új terápiás lehetőségek odontomák kezelésében
}

\author{
Esetismertetés
}

\author{
DR. TRIMMEL BÁLINT, DR. NAGY ZOLTÁN, DR. GYULAI-GAÁL SZABOLCS
}

\begin{abstract}
Az odontomák benignus, hám- és kötőszöveti elemeket vegyesen tartalmazó odontogén daganatok. Irodalmi adatok alapján teljes exstirpatiójuk mellett recidíva ritkán jelentkezik. Esetünkben két évvel korábban operált, complex odontoma recidívájának kétlépcsős mútéti ellátását mutatjuk be. A 20 éves páciens jobb oldali angulus mandibulae területére lokalizálódó abscessusszal jelentkezett, képalkotó felvételek alapján az angulus mandibulaenak megfelelő területet odontomának imponáló képlet és az impaktált jobb alsó bölcsességfog töltötte ki. Az állkapocstörés és nervus alveolaris sérülésveszélye miatt kétlépcsős mútéti eljárás mellett döntöttünk intraoralis feltárásból. Az első műtét során az odontoma eltávolítását, valamint a csontdefektus marsupialisatióját végeztük. 4 hónappal később a második mútét alkalmával eltávolítottuk a jobb alsó bölcsességfogat, valamint a csontdefektust fedő hámborítást. A mútét során a nervus alveolaris inferior nem sérült, a keletkezett csontdefektust platelet-rich fibrinnel töltöttük fel, a mútéti területet per primam zártuk. A gyógyulás komplikációmentesen zajlott, három hónap alatt a korábbi mútéti területen az egészséges anatómiai viszonyok rekonstrukcióját értük el.
\end{abstract}

Kulcsszavak: odontomarecidíva, kétlépcsős mútéti eljárás, platelet-rich fibrin (PRF)

A WHO legutóbbi klasszifikációja szerint az odontomák mesenchymalis és epithelialis elemeket (fog eredetü kemény- és lágyszöveteket) vegyesen tartalmazó benignus daganatok, melyek két típusát különböztetjük meg: a compound és complex odontomát [5]. Az elváltozás az egyik leggyakoribb odontogén daganat, megjelenési aránya a két nem esetén nem mutat eltérést $[2,3]$. Eredetük ismeretlen, a fogcsíra genetikai eltérése, illetve külső környezeti tényezők, például traumák játszhatnak szerepet a kialakulásukban. A genetikai háttér szerepe mellett szól, hogy örökletes szindrómák részeként, például Gardner-, Hermann-, Gorlin-Goltz-szindróma esetén is megfigyelhető jelenlétük [3, 14]. A compound odontoma leggyakoribb előfordulási helye a maxilla frontalis régiója, megjelenése kisméretű fogak halmazára hasonlít, ez a gyakoribb elváltozás. A complex odontoma fogszöveteket tartalmazó szabálytalan masszaként azonosítható, a mandibula hátsó régiójában fordul eló gyakrabban [2, 5]. Az odontomákat általában tünetszegény növekedés jellemzi, panaszokat ritkán okoznak. Fogelőtörési zavar, fájdalmatlan állcsont duzzanat, rágóképesség-csökkenés miatt készített fogászati röntgenen a legtöbb esetben már fiatal korban azonosítható radiodenz képződményként jelennek meg. A szövettani képüket különböző érettségi fokú fogszövetek elegye jellemzi [9, 14]. A kötőszövetes tokkal körülvett amorf képletmassza legnagyobb arány- ban dentint tartalmaz, de a szövettani leletben zománcprizmák is megfigyelhetők. A compound odontóma esetében a különböző szövetek rendezettsége nagyobb, hasonlóságot mutat a maradó fogakhoz.

Differenciáldiagnosztikai szempontból a kalcifikáló odontogén tumorok, ameloblastos fibroma, ameloblastos fibroodontoma, odontoameloblastoma, osteomák, osteoblastomák és cementomák merülnek fel, a diagnózis felállításához minden esetben szövettani vizsgálat szükséges [2].

Odontoma esetén a terápiát a sebészi eltávolítás jelenti, mely a lokalizációtól függően intra- vagy extraoralis megközelítésből végezhető. A mútét során fontos, hogy az elváltozás teljes egészében eltávolításra kerüljön, a mútéti területet gondosan át kell vizsgálni. Amennyiben a mútét során keletkező csontdefektus mérete kiterjedt, csontpótló eljárások alkalmazása is megfontolandó. Annak ellenére, hogy az odontomák kiújulási hajlama megfelelő sebészi eltávolítás mellett csekély, rendszeres kontrollvizsgálatok mellett az esetleges recidíva időben észlelhető [5, 14].

A sebészi exstirpatio lehetséges szövődményei: szomszédos fog illetve fogcsíra sérülése, állcsont törése, ideg-, érképletek sérülése, a mútéti terület felülfertőződése. Az esetleges komplikációk elkerülése szempontjából fontos a beavatkozás pontos megtervezése és gondos kivitelezése, a posztoperatív szakaszban a megfelelő sebtoalett alkalmazása [9, 14]. 


\section{Esetismertetés}

20 éves férfi páciens szájnyitási korlátozottsággal és jobb oldali arcduzzanattal érkezett osztályunkra. A klinikai vizsgálat során a jobb oldali angulus mandibulae területe duzzadt, tapintásra érzékeny volt. Intraoralisan a jobb oldali retromolaris területen a nyálkahártya duzzadt, fájdalmas, fluktuáló tapintatú. Panorámaröntgenfelvétel készítése után (1. kép) szabálytalan, környezetétől elhatárolódó, radiodenz elváltozás látható a bölcsességfog felett, mely a fogat a mandibula bázisához diszlokálta. A páciens elmondása alapján korábban panaszai nem voltak, fogszabályozó kezeléséhez kapcsolódóan az adott területen pár évvel korábban mútéti beavatkozást végeztek.

A kezelés első lépése az akut odontogén gyulladás és a következményes szájzár megszüntetését célozta

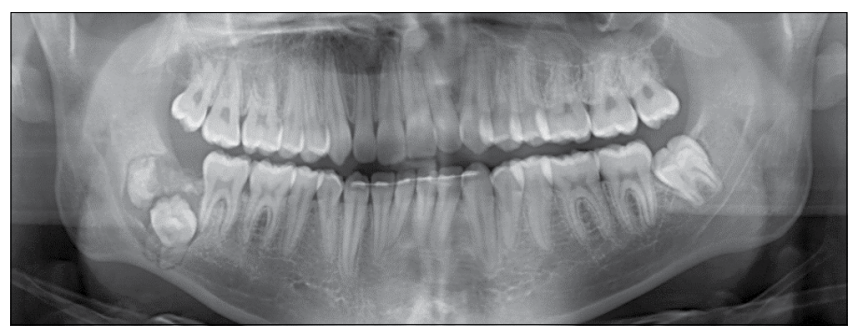

1. kép: Kiindulási panorámaröntgen-felvétel (2019)

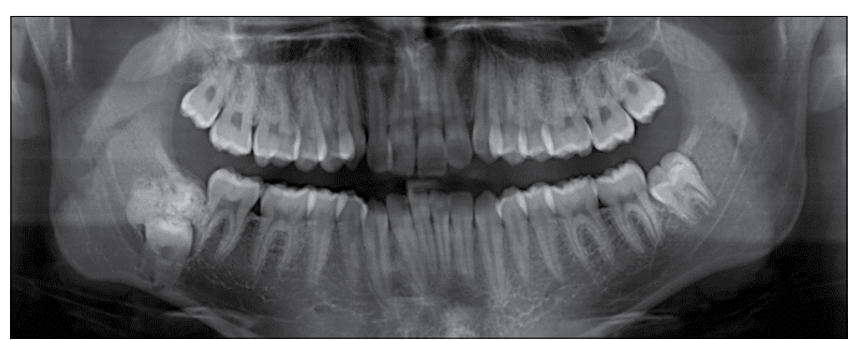

2. kép: Fogszabályozó kezelés előtt készült panorámaröntgen-felvétel (2016)

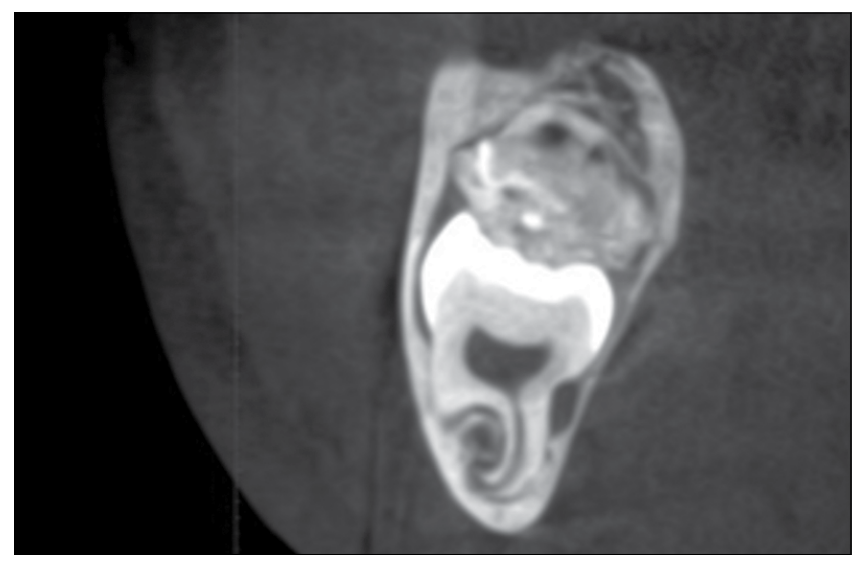

3. kép: CBCT képen az elváltozás és a 48 fog a mandibula $\mathrm{kb}$. 85\%-át kitölti az adott átmetszetben, a nervus alveolaris inferior közvetlen kapcsolatban van a bölcsességfog gyökerével meg. Nervus alveolaris inferior és a nervus buccalis vezetéses érzéstelenítését követően a 47 fog mögötti területen intraoralisan incíziót végeztünk. Az abcessusból nagy mennyiségű, sűrű pus és szövettörmelék ürült, az elváltozás drenálására jodoformos gézcsíkot helyeztünk be. Per os $2 \times 1$ (875 mg/125 mg) amoxicillin + clavulansavat indítottunk, a pácienst másnapra mútétre előjegyeztük. Az anamnézis és a rendelkezésre álló korábbi képalkotó felvételek alapján az elváltozás odontoma recidívának imponált (2. kép). Méretére, valamint a környező anatómia-képletek közelségére tekintettel a mútét során csupán az elváltozás teljes eltávolítására törekedtünk, a jobb alsó bölcsességfog eltávolítását kockázatosnak ítéltük (3. kép). Az angulus mandibulae területén keletkezett állcsontdefektust a szájüreg melléküregévé alakítva, annak marsupialisatióját terveztük, lehetőséget teremtve a csontregenerációra, ezzel biztosítva egy későbbi mútét során az esetleges állcsonttörés, valamint idegsérülés minimalizálását. A 47 fog mögött képzett L-alakú lebenyből hozzáférve eltávolítottuk az elváltozást körülvevő kötőszövetes tokot, illetve több darabban az amorf formájú terimét. $A$ műtét során a buccalis csontfal megőrzésére törekedtünk. A mútéti területet nagy mennyiségú, fiziológiás sóoldattal mostuk át, a visszamaradt csontdefektust jodoformos gézcsíkkal tamponáltuk, majd a lebenyt eredeti pozícióba viszszafektettük, egyszerű csomós öltésekkel egyesítettük. A páciens rendszeres kontrollja mellett marsupialisaltuk az elváltozást. A jodoformos gézcsíkot naponta cseréltük, majd a csontdefektus hámosodása után perubalzsamos gézcsíkra tértünk át, melyet heti két alkalommal cseréltünk és naponta háromszor $0,12 \%$-os klórhexidin oldat használatát rendeltük el [10].

Az eltávolított elváltozás szövettani értékelése igazolta a complex odontoma diagnózist.

Rendszeres kontrollok során az elváltozással érintett, jobb alsó második őrlőfog szenzitivitás-vizsgálatát is több alkalommal elvégeztük. Az érintett fog a referencia fogakhoz képest nem reagált hideg ingerre, pulpanekrózis miatt a fog endodontiai kezelését a második mútét előtt elvégeztük [11]. A marsupialisatiónak köszönhetően 4 hónap alatt a csontdefektus mérete jelentősen csökkent, kontroll röntgenfelvételen a canalis mandibulae felett újonnan képződött csontállomány ábrázolódott, így az áttörésben visszamaradt bölcsességfog eltávolítása mellett döntöttünk. A retenció mélysége, illetve a bölcsességfog gyökerei között futó nervus alveolaris inferior helyzete miatt opcióként merült fel a 47 fog disszekciója és a distalis gyökér eltávolítása a mútét során, így biztosítva jobb hozzáférést a 48 foghoz. A mútét okozta csontdefektus feltöltésére, az eredeti anatómiai viszonyok rekonstruálására a szakirodalomban számos graftanyag használatát leírták már, a véralvadék stabilizálását elősegítő kollagénszivacsoktól a különböző csontpótló anyagokig [13]. A regeneratív anyagok használata a defektus gyorsabb és tökéletesebb telődését eredményezi $[6,13]$, csökkentheti a posztoperatív szövődmények mértékét, rövidítve a gyó- 
gyuláshoz szükséges időt. E tekintetben különösen ígéretes az autológ vérlemezke-készítmények postextractiós alkalmazása [12, 15]. A második mútét során a mútéti terület feltöltéséhez advanced platelet-rich fibrin (A-PRF) alkalmazása mellett döntöttünk, a pácienstől a mútét előtt összesen $8 \times 10 \mathrm{ml}$ vért vettünk [7]. Choukroun-protokoll szerint a natív A-PRF csöveket 14 percig $1300 \mathrm{rpm}$ fordulaton centrifugáltuk. Az eljárás során a véralvadási folyamatnak köszönhetően a kémcső tetején egy sárgás színű, gél állagú, fibrinalvadékhoz jutunk. Ez a fibrin mátrix vérlemezkék mellett leukocytákat és plasmaproteineket is tartalmaz. A kialakult 3D struktúra vérlemezke és leukocyta eredetű növekedési faktorok (inzulinszerű növekedési faktor-I (IGF-I); interleukin-1 (IL-1); interleukin-4 (IL-4); interleukin-6 (IL-6); interleukin-10 (IL-10); epidermalis növekedési faktor (EGF); hepatocyta növekedési faktor (HGF); thrombocytaeredetü növekedési faktor (PDGF); transzformáló növekedési faktor- $\beta$ (TGF- $\beta$ ); érendothel növekedési faktor (VEGF) rezervoárjaként funkcionál, szerkezeti stabilitását kb. 14 napig megtartva a gyógyulási folyamatokat irányító bioaktív molekulák konstans jelenlétét biztosítja [4, 8]. Az így előállított graftanyag teljesen autológ, szöveti reakciót nem okoz. A magas leukocytatartalom csökkenti a mútéti terület felülfertőződését, korábbi klinikai vizsgálatok ödémaképződés csökkenéséről, jobb lágyszöveti és csontregenerációról számoltak be [1, 12].

A második mútétet az elsőhöz hasonlóan vezetéses érzéstelenítés mellett végeztük. L-alakú, mucoperiostealis lebenyképzést követően eltávolítottuk a marsupialisatio során létrehozott melléküreg hámborítását. Ezt követően a buccalis csontfalat csontfrézerek segítségével eltávolítva, szabaddá tettük a bölcsességfog buccalis felszínét. A fog koronai részén retenciós mélyedést kialakítva, emelő segítségével a fog óvatos luxálását végeztük, majd a bölcsességfogat mesiodistalis irányban disszekáltuk. A két darabot fokozatos, körültekintő luxálás mellett sikerült a 47 fog sérülése nélkül eltávolítani. A beavatkozás során a nervus alveolaris inferior és a mandibula folytonossága is intakt maradt. A mútéti területet fiziológiás sóoldattal mostuk át, a szövettörmelékeket és nyálkahártya részleteket alaposan excaváltuk, a 47 fog distalis gyökérfelszínének simítását is elvégeztük. A visszamaradt csontdefektust A-PRF alvadékkal töltöttük fel, a lebenyt egyszerű csomós öltésekkel per primam zártuk (4. kép).

A mútétet követően per os ( $875 \mathrm{mg} / 125 \mathrm{mg})$ amoxicillin + clavulánsavat indítottunk naponta $2 \times 1$ adagban egy héten át. Az egy héttel későbbi kontrollon a páciens a nervus alveolaris inferior területén paraesthesiát nem jelzett, minimális arcduzzanatról és érzékenységről számolt be. A seb záródott, felülfertőződés nem következett be, a varratokat ekkor távolítottuk el.

A három hónapos kontroll során készített panorámaröntgen-felvételen a mütéti terület csontos telödése látható, a jobb alsó második őrlő distalis gyökerénél a pe-

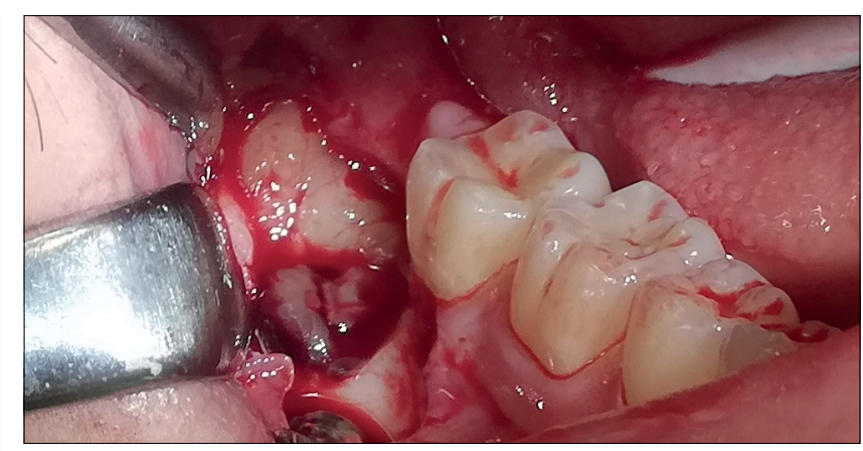

4. kép: A bölcsességfog eltávolítása után a defektus feltöltése platelet-rich fibrinnel (2. mútét)

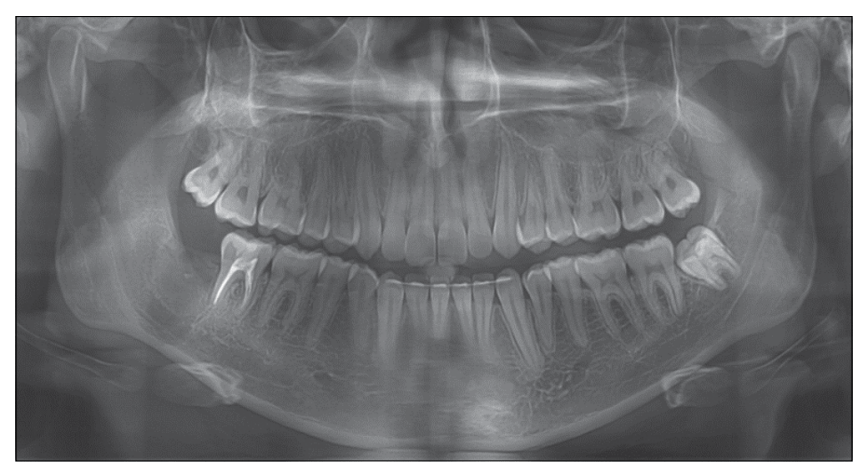

5. kép: Kontroll panorámaröntgen-felvétel három hónappal a második mútét után

riapicalis rajzolat egészséges szerkezetú, egészen a fognyaki régióig követhető (5. kép).

A féléves kontroll CBCT felvételen jól látható, hogy a jobb alsó második őrlőfog distális gyökere körül ép a gyökérhártya-rajzolat és a csontszerkezet a korábbi mútéti területen (6. kép).

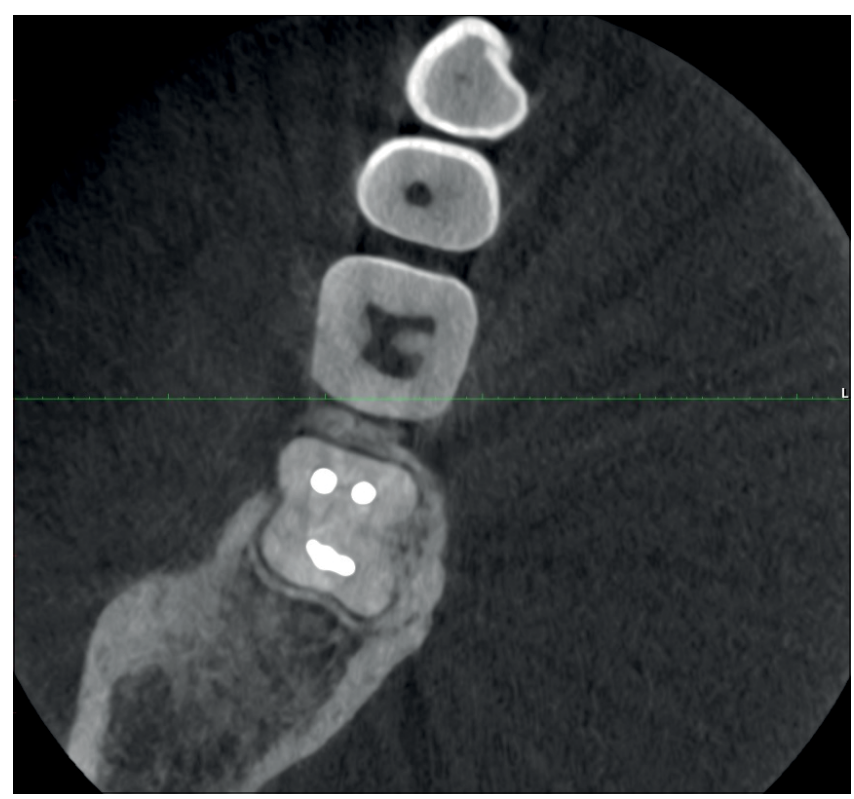

6. kép: CBCT felvétel horizontális metszete a 47 fog fognyaki régiójában hat hónappal a második mútét után 


\section{Megbeszélés}

Az odontomák a leggyakrabban előforduló jóindulatú odontogén daganatok közé tartoznak. Diagnózisukat megnehezíti tünetszegény növekedésük, mely következtében az állcsontok deformációja, szomszédos fogak diszlokációja, károsodása is előfordulhat. Sok esetben csak radiológiai vizsgálat során kerülnek felismerésre, biztos diagnózisuk szövettani vizsgálat alapján állítható fel. Terápiája minden esetben sebészi eltávolításból áll. Szövődményként nagy kiterjedésű elváltozások esetén a környező anatómiai struktúrák sérülése, állcsonttörés fordulhat elő.

Bemutatott esetünk is felhívja a figyelmet a mútét utáni szoros kontroll fontosságára. Irodalmi adatok alapján az odontomák kiújulásra nem hajlamosak, viszont a nem teljesen eltávolított elváltozások későbbi recidívák forrásai lehetnek. Az általunk a mindennapos szájsebészeti ellátásban sikeresen alkalmazott oszteoinduktív PRF technika egy újabb indikációs területe került bemutatásra, amivel a hasonló nagy kiterjedésú elváltozások esetén többlépcsős mútéti ellátás részeként, az eredeti anatómiai viszonyokat sikeresen rekonstruálhatjuk.

\section{Köszönetnyilvánítás}

A szerzők ezúton köszönik Dr. Dobó-Nagy Csabának a kézirat lektorálását és megjelenésének támogatását.

\section{Irodalom}

1. Al-Hamed FS, Tawfik MAM, Abdelfadil E, Al-Saleh MAQ: Efficacy of Platelet-Rich Fibrin After Mandibular Third Molar Extraction: A Systematic Review and Meta-Analysis. Journal of Oral and Maxillofacial Surgery 2017; 1124-1135. https://doi.org/10.1016/j.joms.2017.01.022

2. Avelar RL, Primo BT, Pinheiro-Nogueira CB, Studart-Soares EC, De Oliveira RB, Romulo de Medeiros J, et al: Worldwide incidence of odontogenic tumors. J Craniofac Surg 2011; 2118-2123. https://doi.org/10.1097/SCS.0b013e3182323cc7

3. Bianco BCF, Sperandio FF, Hanemann JaC, Pereira aAC: New WHO odontogenic tumor classification: impact on prevalence in a population. J Appl Oral Sci 2020; e20190067. https://doi.org/10.1590/1678-7757-2019-0067

4. Caruana A, Savina D, Macedo JP, Soares SC: From Platelet-Rich Plasma to Advanced Platelet-Rich Fibrin: Biological Achievements and Clinical Advances in Modern Surgery. European journal of dentistry 2019; 280-286. https://doi.org/10.1055/s-0039-1696585

5. El-Naggar AK, Jennifer RG, Takashi T, Slootweg PJ: WHO Classification of Head and Neck Tumours. Fourth edition. In: Lyon,. International Agency for Research on Cancer 2017: 224-226.

6. Gasparro R, Sammartino G, Mariniello M, Di Lauro AE, SpAgnuolo G, MARENZI G: Treatment of periodontal pockets at the distal aspect of mandibular second molar after surgical removal of impacted third molar and application of L-PRF: a split-mouth randomized clinical trial. Quintessence Int 2020; 204-211.

7. Ghanaati S, Booms P, Orlowska A, Kubesch A, Lorenz J, RUTKOWSKI J, et al: Advanced platelet-rich fibrin: a new concept for cell-based tissue engineering by means of inflammatory cells. J Oral Implantol 2014; 679-689. https://doi.org/10.1563/aaid-joi-D-14-00138

8. Ghanaati S, Herrera-Vizcaino C, Al-Maawi S, Lorenz J, Miron RJ, Nelson K, et al: Fifteen Years of Platelet Rich Fibrin in Dentistry and Oromaxillofacial Surgery: How High is the Level of Scientific Evidence? J Oral Implantol 2018; 471-492. https://doi.org/10.1563/aaid-joi-D-17-00179

9. Gyulai-GaÁl S, TaKács D, Barabás J, Tarján I, MartonfFy K, Szabo G, et al.: Mixed odontogenic tumors in children and adolescents [Fogelőtörési zavarokkal járó vegyes odontogén daganatok]. Fogorvosi Szemle 2007; 65-69.

10. Mensch K, Pongracz J, Nagy A, Kristof K, Bechir A, Pacurar M, et al: Preventive and Therapeutic Effects of Chlorhexidine Containing Varnish on Candida Biofilm. Revista De Chimie 2017; 2808-2811. https://doi.org/10.37358/RC.17.12.5983

11. Mensch K, Simonffy L, Dombi C, Szabo BT, Varga J, Juhasz A, et al: Endodontic and microsurgical treatments of maxillary lateral incisor dens invaginatus in combination with cone-beam-computed tomography fusion imaging. Oral Radiology 2017; 147-152. https://doi.org/10.1007/s11282-016-0257-5

12. Ritto FG, Pimentel T, Canellas JVS, Junger B, Cruz M, MedeIRos PJ: Randomized double-blind clinical trial evaluation of bone healing after third molar surgery with the use of leukocyteand platelet-rich fibrin. Int J Oral Maxillofac Surg 2019; 1088-1093. https://doi.org/10.1016/j.ijom.2019.01.020

13. Simonffy L, Minya F, Trimmel B, Lacza Z, Dobo-Nagy C: Albumin-Impregnated Allograft Filling of Surgical Extraction Sockets Achieves Better Bone Remodeling Than Filling with Either Blood Clot or Bovine Xenograft. Int J Oral Maxillofac Implants 2020; 297-304. https://doi.org/10.11607/jomi.7554

14. SzÜTS J, NÉMETH Z: Diagnosis and treatment of odontomas in the maxillofacial surgery [Odontómák diagnosztikus és terápiás aspektusai a maxillofacialis sebészetben]. Fogorvosi Szemle 2018; 85-90.

15. Varghese MP, Manuel S, Kumar LKS: Potential for Osseous Regeneration of Platelet-Rich Fibrin-A Comparative Study in Mandibular Third Molar Impaction Sockets. Journal of Oral \& Maxillofacial Surgery (02782391) 2017; 1322-1329. https://doi.org/10.1016/j.joms.2017.01.035 
Trimmel B, Nagy Z, Gyulal-Gá́l Sz

\section{New therapeutic options in the treatment of odontomas}

A case report

Odontoma is a benign, odontogenic tumour composed of mixed epithelial and mesenchymal tissues. Based on the literature recurrence is rare after complete extirpation. In our case, we present a two-stage surgical treatment approach for a recurrent complex odontoma, which was first operated two years earlier. The twenty-year-old patient presented an abscess localized to the area of the right mandibular angle. The radiological images, revealed an area filled with an odontoma-like lesion and the impacted lower wisdom tooth. Due to the risk of jaw fracture and alveolar nerve injury, a twostage surgical procedure was applied from intraoral access. During the first surgery, the odontoma was removed and the bony defect was marsupialized. Four months later, the right lower wisdom tooth and the epithelial lining of the bony defect were removed. The second surgery was performed without alveolar nerve injury, the bony defect was filled with platelet-rich fibrin and primarily wound-closure was applied. Healing was uneventful. During three month healing time the original anatomical conditions were reconstructed in the previous surgical area.

Keywords: recurrent complex odontoma, two-stage surgical treatment, platelet-rich fibrin (PRF) 